\title{
Production Technology for the Wild Berberis lycium Fresh Mass Production in Control Chamber at Low Altitute Area
}

\author{
Tahseen Ullah* and Noorul Amin
}

Department of Horticulture, The University of Agriculture Peshawar, Khyber Pakhtunkbwa, Pakistan.

\begin{abstract}
Berberis (Berberis lycium L.) locally know as Kora in hilly area of upper Swat is an important medicinal plant. An investigation to find out the effect of rooting hormones and types of stem cutting on the rooting of Berberis (Berberis lycium L.) was conducted at Horticulture Research Institute, National Agriculture Research Centre, Islamabad, Pakistan during the year 2016-2018. The experiment was laid out in Complete Randomized Design, with two factors i.e. three different level of indole butyric acid (IBA 2000, IBA 4000 and IBA $6000 \mathrm{ppm}$ ) and three types of cutting (Soft wood, Semi Soft wood and Hard wood cutting). The basal ends of the cutting were immersed in the desired strength of the IBA. After treating the cuttings with solution they were planted in raised beds and covered with plastic sheets to maintain the humidity in the experiment plots. Types of stem cutting and IBA concentration have significantly affected (at $\mathrm{P} \leq 0.05)$ the sprouting \%, survival \%, sprout weight, dry leaves weight, leaf area, root diameter, chlorophyll content, sprout diameter, fresh root weight, number of branches, shoot length and root length while the days to bud sprouting, fresh leaves weight and number of roots have non-significantly affected by IBA concentration and types of stem cutting. The results had shown that sprouting percentage was highest $(99.33 \%)$ in hard wood cutting while minimum sprouting $(20 \%)$ in soft wood cutting treated with IBA 6000 ppm while highest survival rate of $85.23 \%$ in soft wood cutting, highest sprout weight of $14.37 \mathrm{~g}$, highest shoot length $(30.8 \mathrm{~cm})$ and maximum number of branches (6) was found in hard wood cutting treated with IBA 6000 ppm while maximum fresh root weight $(4.2267 \mathrm{~g})$, maximum root length $(32.75 \mathrm{~cm})$ and highest root diameter $(2.49$ $\mathrm{mm}$ ) in hard wood cutting treated with IBA $4000 \mathrm{ppm}$. Therefore, hard wood cutting with IBA $4000 \mathrm{ppm}$ is recommended for the propagation of Berberis lycium from cutting.

Received | December 16, 2019; Accepted | November 10,2020; Published | July 12, 2021

*Correspondence | Tahseen Ullah, University of Agriculture Peshawar, Khyber Pakhtunkhwa, Pakistan; Email: tahseenullah@hotmail.com

Citation | Ullah, T. and N. Amin. 2021. Production technology for the wild Berberis lycium fresh mass production in control chamber at low altitute area. Sarhad Journal of Agriculture, 37(3): 999-1008.

DOI | https://dx.doi.org/10.17582/journal.sja/2021/37.3.999.1008

Keywords | Berberis lycium, Production technology, Indole butyric acid cutting treatment, Clonal propagation, Vegetative cutting
\end{abstract}

\section{Introduction}

$B$ erberis lycium is a well known medicinal plant commonly used in traditional herbal medicines and recipes for number of ailments. It is native to India, Pakistan and Himalayas region. The Berberis lycium belong to the family Berberidaceae and genus Berberis. The Berberidaceae family includes 12 genera and 600 species. (Rao et al., 1998). The genus berberis may be found widely all over the world mainly in India, Pakistan, West and Central Asia, China, Japan, South-east Asia, Europe, East Africa, North America and South America (Bhardwaj and Kaushik, 2012; Rao and Hajra, 1993). The major species found widely and reported are Berberis vulgaris, Berberis lycium and Berberis aristate. The plants are spiny, evergreen and produce yellow flower. It is commonly found in hilly track of upper northern area, Swat, Murree and 
Galliyat Hills. It produces flower in April-May and small black and yellow berry fruit in June. In upper swat area, the plant is commonly known as Kora while in Murree and Galliyat it is locally known as pilla sudo/ sumbal or kala sudo/ sumbal. Pilla sudo produce yellow berry fruit while kala produce black berry fruit. Such classification at local level seems due to its fruit colour.

The Berberis has been known for its traditional use in medicine since ancient time. The stem, roots and roots bark have been used in Ayurvedic, Homeopathic and ethno-medicines as raw materials or as an ingredient. It has been reported in various studies that it's used as anti-diabetic, anti-diarrheal, anti-inflammatory, hepto-protective, antimicrobial, Cardio-tonic, ophthalmic, anti-depressant, anti-tumor and immune-modulatory (Bhardwaj and Kaushik, 2012). The use of barberry fruit as blood purifying agent was engraved on the clay tablets in library of Assyrian emperor (Present day Iraq) during 650 BC (Karimov, 1993) The genus berberis has been reported for its medicinal value and properties due to the presence of important phytoconstituents. Karimov (1993) tabulated 76 Berberis species and the alkaloids isolated from them. He listed 129 new alkaloids in his review paper belonging to 16 different groups. Literature review revealed that during last three decades focusing on taxonomical aspects, and isolation, identification of new compounds from berberis Moreover, studies on the distribution, botanical aspects, phytochemical analysis, pharmacology and pharmacological properties (Antidiabetic, antihyperlipidemic, hepatoprotective, antimicrobial, antimutagenic, pesticidal and wound healing properties of the berberis were also carried out in different part of the world (Bhardwaj and Kaushik, 2012; Shabbir et al., 2012; Ikram, 1975).

However, little work has been done on conservation and propagation of Berberis lycium in different agroclimatic regions. The present study is an attempt to study its propagation and to optimize clonal propagation protocol and evaluate it production in different agro-ecological zone for suitable cultivation on commercial scale. Although some studies have been reported for its in vitro propagation from Azad Jammu Kashmir region. However, the success through in vitro propagation is not only difficult in woody plant as the response of woody plants is slow in tissue culture but also costly. The clonal propagation through cutting on other side is successful and cost effective. Therefore, its propagation from clonal way will be the first to report in low altitude region with different agro-ecological parameters, under partial control environment. This may be breakthrough in its propagation and cultivation on mass scale.

\section{Materials and Methods}

The experiment titled "Production technology for wild Berberis lycium fresh mass productions in control chamber at low altitude area" was carried out at the Green House of Horticulture Research Institute, National Agriculture Research Centre, Islamabad Pakistan, during 2017-2018.

\section{Experiment design and treatment combination}

The experiment was laid out in Completely Randomized Design (CRD) repeated three times. The total numbers of treatments were 12 . Three different types of stem cuttings (Hard, Semi Hard and soft wood) of Berberis lycium were dipped in four different concentrations of IBA i.e. 0 (Control), 2000, 4000 and $6000 \mathrm{ppm}$. The number of cutting per treatment was 10 , so the total number of cuttings used in the whole experiment was 810 .

\section{Treatment combinations along with its label.}

$\begin{array}{lll}\text { Types of cutting } & \text { Concentration } & \text { Treatment label } \\ \text { Soft wood } & 2000 \mathrm{ppm} & \text { T1 } \\ & 4000 \mathrm{ppm} & \text { T2 } \\ & 6000 \mathrm{ppm} & \text { T3 } \\ & \text { Control } & \text { T4 } \\ \text { Semi hard } & 2000 \mathrm{ppm} & \text { T5 } \\ & 4000 \mathrm{ppm} & \text { T6 } \\ & 6000 \mathrm{ppm} & \text { T7 } \\ & \text { Control } & \text { T8 } \\ \text { Hard wood } & 2000 \mathrm{ppm} & \text { T9 } \\ & 4000 \mathrm{ppm} & \text { T10 } \\ & 6000 \mathrm{ppm} & \text { T11 } \\ & \text { Control } & \text { T12 }\end{array}$

\section{Preparation of cutting}

Hardwood, Semi hardwood and softwood cuttings of Berberis lycium were taken from the National Herbarium Nursery at NARC, Islamabad. The cuttings used were having uniform size, $20 \mathrm{~cm}$ longs with four buds and two to three leaves.

\section{Application of rooting hormones (IBA)}

Indole butyric acid (IBA) was prepared according to the formula i.e. $1 \mathrm{mg}$ of hormones in 1 litre of 
distilled water to make $1 \mathrm{ppm}$ solution. As IBA is available in crystal form, so it was initially dissolved in $90 \%$ ethanol before adding distilled water to make the required strength. The basal ends of the cutting were immersed in the required strength of the rooting hormones (IBA) for 1 minute.

\section{Plantation of cuttings}

After treating the cuttings with desired strength of IBA, the cuttings were planted in raised beds at depth of $6-10 \mathrm{~cm}$. The beds contain mixture of the sand and silt. The bed was covered with polyethylene sheets, in order to arrest proper humidity inside the plastic. Experimental area was irrigated immediately after plantation of the cutting. Regular irrigation was applied to the cuttings in addition to all the cultural practices like hoeing, weeding and irrigation were kept uniformly as usual during the research work.

\section{Attributes studied}

The various attributes were studied during the course of the experiment include: Days to bud sprouting, Sprouting percentage, Shoot length, shoot diameter, shoot weight, root weight, number of roots and leaf area The number of days to sprouting was collected from the date of planting and then average values were calculated. The sprouting percentage of cuttings was worked out using the following formula:

$$
\text { Sprouting } \% \text { age }=\frac{\text { Total no. of sprouted cuttings }}{\text { Total no. of planted cuttings }} \times 100
$$

Sprout length $(\mathrm{cm})$ of the main shoot of each plant was measured with the help of measuring tap in $\mathrm{cm}$ from the base to apex of the plant and average shoot length was calculated. Thickness of the surviving shoots that emerged from the cutting was measured with the help of digital Vernier calliper in millimetre $(\mathrm{mm})$ and then average was calculated to determine sprout diameter. The unit for measurement was millimetre $(\mathrm{mm})$. Fresh Sprout/Shoot weight was calculated by taking of mass of sprout using four digit gram balance. The unit of measure was gram (g). Number of Branches in each treatment was calculated by randomly selecting 7 sprouted cutting in each treatment and average was calculated. Fresh leaves weight was calculated using four digits in gram. Seven leaves were randomly selected from top, middle and near stem area of sprout. Each leaf was weighted and average value was taken as fresh leave weight in each treatment. The chlorophyll content was taken with spade meter from randomly seven leaves from top, middle and near stem region of sprout/shoot by calculating average value of each treatment. Leaf area was calculated by taking randomly seven leaves from each treatment by using petiole 2 method as described by (Polunina et al., 2018). The unit for leaf area measure was $\mathrm{cm}^{2}$. Leaf mass ratio was calculated by dividing fresh mass over area. The unit of measure for Leaf Mass ratio is $\mathrm{mg} / \mathrm{cm}^{2}$. The formula for Leaf Mass ratio is given below:

$$
\text { Leaf mass ratio }=\frac{\text { Leaf mass or weight }}{\text { Area }}
$$

Specific leaf Area $\left(\mathrm{cm}^{2} . \mathrm{mg}^{-1}\right)$ specific leave area was calculated using by dividing leaf area over leaf dry weight or mass. The unit of measure for Specific Leaf Area is $\mathrm{cm}^{2} / \mathrm{mg}$. The formula for specific leaves area is given below:

$$
\text { Specific leaf area }=\frac{\text { Area }}{\text { Mass }}
$$

Leaves were dry in semi shad area for 48-72 hours Dry leaves weight was calculated using four in gram. Seven leaves were randomly selected from top, middle and near stem area of sprout. Each leaf was weighted and average value was taken as fresh leave weight in each treatment.

Number of roots plant ${ }^{-1}$ was determined in each treatment by randomly selecting ten plants. While digging the plant out to record number of roots per cutting the root system was exposed by washing gently with water to remove the soil particles. After washing the total number of roots of each cutting was counted and average was calculated. Root length $(\mathrm{cm})$ was measured in each treatment by randomly selecting ten plants. The root system of selected plants were exposed by washing gently with water to remove the soil particles. After washing length of root was taken with the help of measuring tap in centimetre and then average was calculated. Root weight was measured of the randomly selected plants in each treatment and then their average was calculated. Thickness of the surviving root that emerged from the cutting was measured with the help of digital Vernier calliper and then average was calculated to determine Root Diameter ( $\mathrm{mm}$ ). The unit for measurement was millimetre $(\mathrm{mm})$. Total plants of all the treatments in each replication were periodically kept under 
observation and at the end of experiment percent plant survival was recorded by the following formula to determine Survival Percentage:

$$
\text { Survival } \% \text { age }=\frac{\text { Total no. of survived plants }}{\text { Total no. of sprouted cutting }} \times 100
$$

\section{Statistical analysis}

The data on various parameters were recorded and analysed using statistical software Statistix version 8.1 for analysis of variance @ $0.5 \%$ level of probability. Least Significant Test (LSD) was applied for significant data to determine the significance difference in the treatments means. M.S Excel was used for data tabulation and graphical presentation of data (Jan et al., 2009).

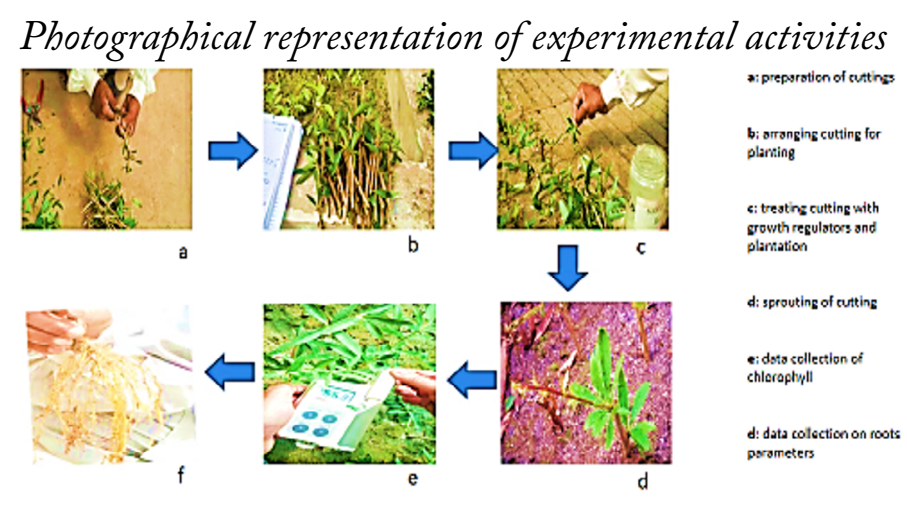

\section{Results and Discussion}

The research study to investigate the production of wild Berberis lycium plants in control environment at low altitude out of its natural habitat was carried out at Horticulture Research Institute, NARC, Islamabad during 2017-18. The mean values of different parameters are presented in Figures 1-4 while ANOVA is given in Table 1 . To check the response of various growth regulator and types cutting types on the growth and production of wild Berberis lycium specie are discussed below.

\section{Days to bud sprouting}

Growth regulators (IBA) and cutting types had no significant effects on number of days to bud sprouting. Maximum days were taken by soft wood treated with IBA 2000 ppm (18.5 days), while minimum days (15.4 days) were taken by hard wood cutting treated with IBA 2000 ppm. Similarly, Fresh leave weight was also none significantly affected by IBA and cutting types at $0.05 \%$ level $(\mathrm{P} \leq 0.05)$ of probability. This may be IBA is root promoting hormones may not have direct influence on days to bud sprouting while the hard wood cutting have taken the minimum days to sprouting might be fact that due high store food content in hard wood cutting may have influence early bud sprouting.

\section{Sprouting percentage}

Data regarding bud sprouting of Berberis lycium is graphical represented in Figure 1. Bud Sprouting percentage was significantly $(\mathrm{P} \leq 0.05)$ affected by different concentration of IBA and types of cutting. Maximum sprouting percentage was observed in hard wood cutting treated in control (99.33\%) followed by hard wood cutting treated with IBA 2000 ppm (80 $\%)$, Semi hard wood cutting in control (80\%) and soft wood cutting sprouting percentage (70\%) minimum sprouting percentage was notice in soft wood cutting (20\%) treated with IBA $6000 \mathrm{ppm}$. The result also shows that sprouting percentage was highest in control where no IBA was applied means that IBA as rooting hormones have no direct influence on sprouting percentage. Bud dormancy and sprouting is having influence by abscisic acid as deliberated in hormonal regulation of bud dormancy (Atwell et al., 1999). Similarly, highest number of branches shoot length and shoot weight was also observed hard wood cutting.

\section{Sprout length (cm)}

Data regarding Sprout/Shoot length as affected by different concentration of IBA and cutting types are shown in Figure 1 and its ANOVA is presented in Table 1.

Shoot length was significantly $(\mathrm{P} \leq 0.05)$ affected by IBA concentration and types of stem cutting. Maximum shoot length $(30.8 \mathrm{~cm})$ was observed in hard wood cutting treated with IBA 6000 ppm while minimum shoot length $(1.33 \mathrm{~cm})$ was recorded in soft wood control.

\section{Sprout diameter ( $\mathrm{mm}$ )}

Data regarding sprout diameter as affected by different concentration of IBA and cutting types are shown in Figure 1, while its ANOVA is presented in Table 1.

Plant Sprout diameter was significantly $(\mathrm{P} \leq 0.05)$ affected by IBA concentration and types of stem cutting. Maximum sprout diameter $(3.46 \mathrm{~mm})$ was recorded in hard wood cutting treated with IBA 6000 ppm. While minimum sprout diameter $(1.3 \mathrm{~mm})$ was 
observed in soft wood cutting treated with IBA 4000 ppm.

\section{Sprout weight (g)}

Data regarding Plant Sprout Weight as affected by different concentration of IBA and cutting types are shown in Figure 2, while its ANOVA is given in Table 1.

Plant sprout weight was significantly $(\mathrm{P} \leq 0.05)$ affected by different concentration of IBA and types of cutting. Maximum Sprout weight (14.378 g) was notice in hard wood cutting treated with IBA 6000 ppm while minimum sprout weight $(0.9633 \mathrm{~g})$ was observed in hard wood cutting in control. Similarly, minimum days to bud sprout, highest sprouting percentage was observed in hard wood cutting. Early sprouting supported maximum weight sprout weight as observed in days to bud sprouting and sprouting percentage. It is also reported that auxins increase the mobilization of store food by enhancing the activities of hydrolytic enzymes.

\section{Number of branches}

Data regarding number of branches as affected by different concentration of IBA and cutting types are shown in Figure 2, while its ANOVA is presented in Table 1.

Number of branches had significantly $(\mathrm{P} \leq 0.05)$ affected by IBA concentration and types of stem cutting, maximum number of branches (6) was recorded in hard wood cutting treated with IBA 6000 ppm. While minimum number of branches (0.667) was notice in semi hard wood cutting treated with IBA 4000 ppm.

\section{Fresh leaves weight (g)}

Data regarding fresh leaves weight as affected by different concentration of IBA and cutting types are shown in Figure 2, while its ANOVA is presented in Table 1.

Types of cutting and IBA concentration had nonsignificant $(\mathrm{P} \leq 0.05)$ affected the Plant Fresh Leaves weight. However, maximum Fresh Leaves Weight $(0.2369 \mathrm{~g})$ was recoded in hard wood cutting in control while minimum Fresh Leaves Weight (0.0277

g) was observed in hard wood cutting treated with IBA 6000 ppm.

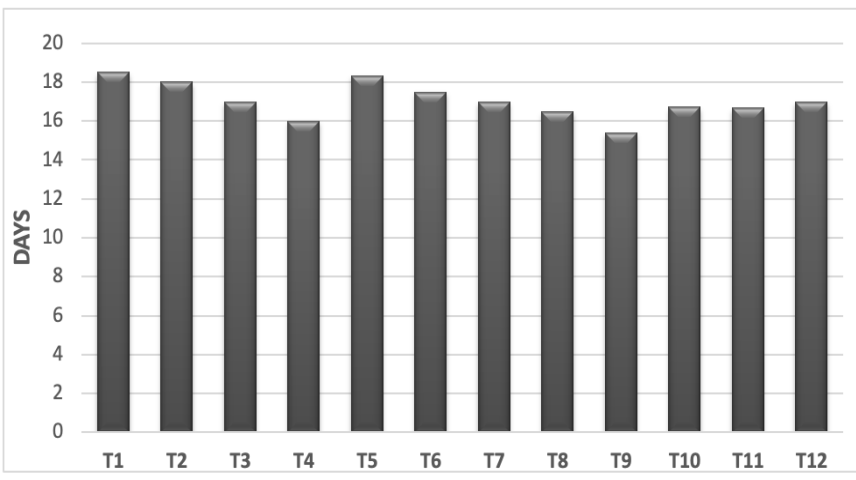

a

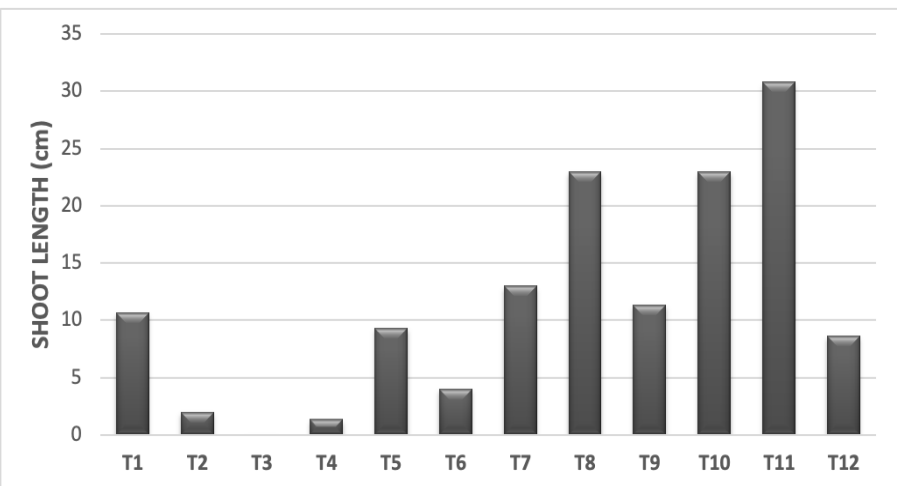

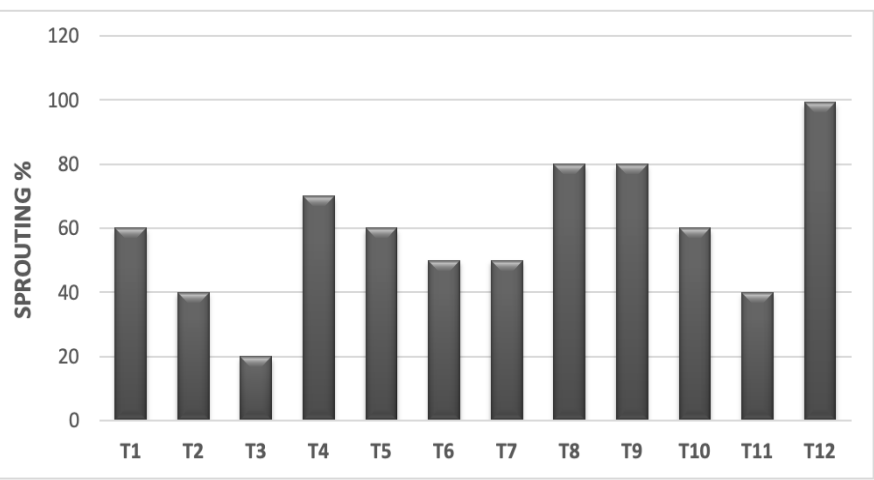

b

C

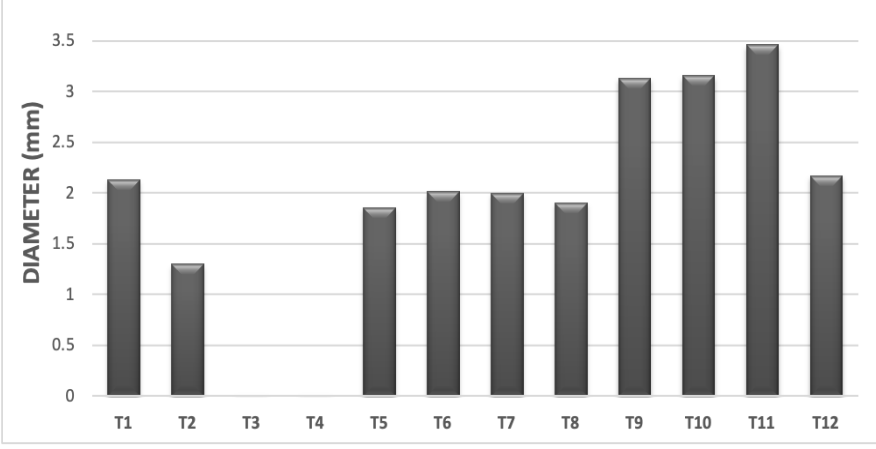

d

Figure 1: Effect of IBA concentration and types of cutting on (a) days to sprouting (b) sprouting percentage (c) Shoot length and (d) Shoot diameter. 


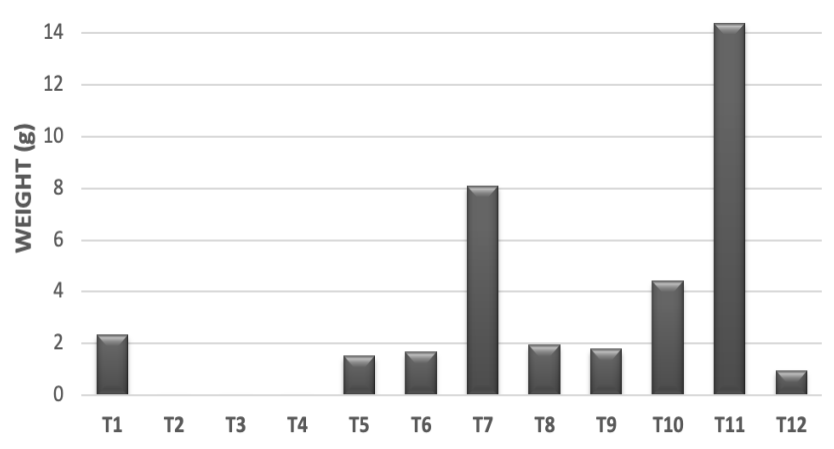

a

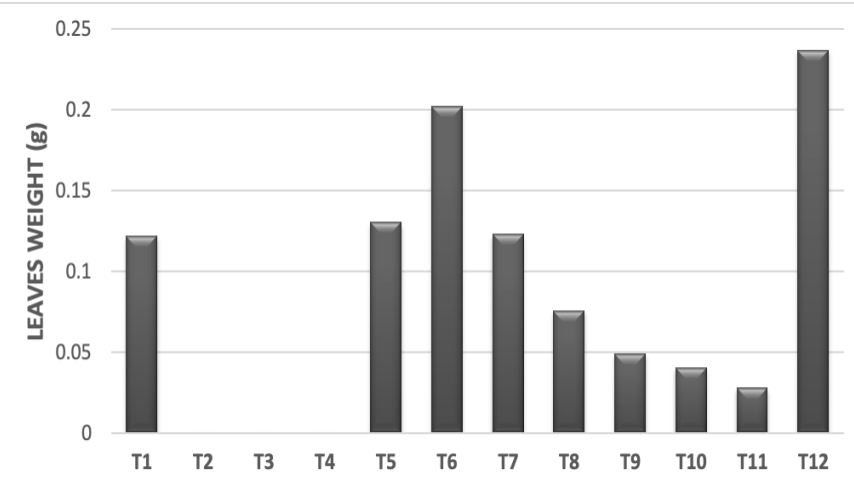

C

Figure 2: Effect of IBA concentration and cutting types on (a) sprout weight (g), (b) Number of Branches, (c) Fresh Leaves Weight (g) and (d) Chlorophyll Content in Berberis lycium.

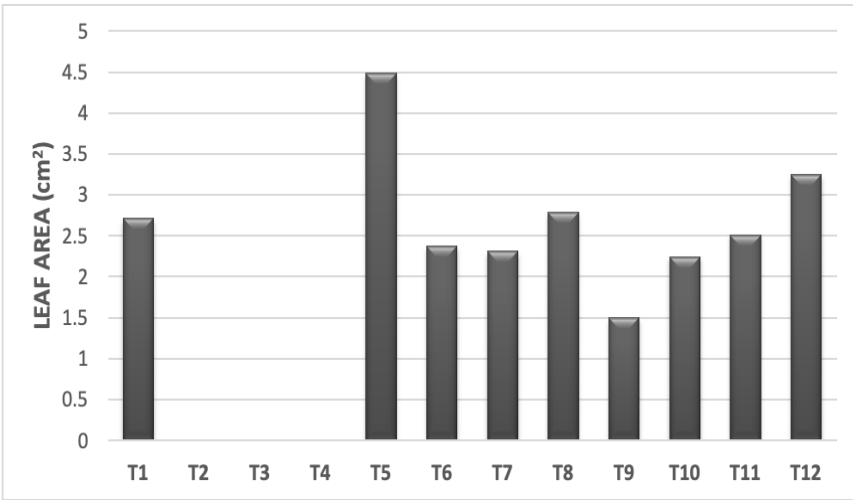

a

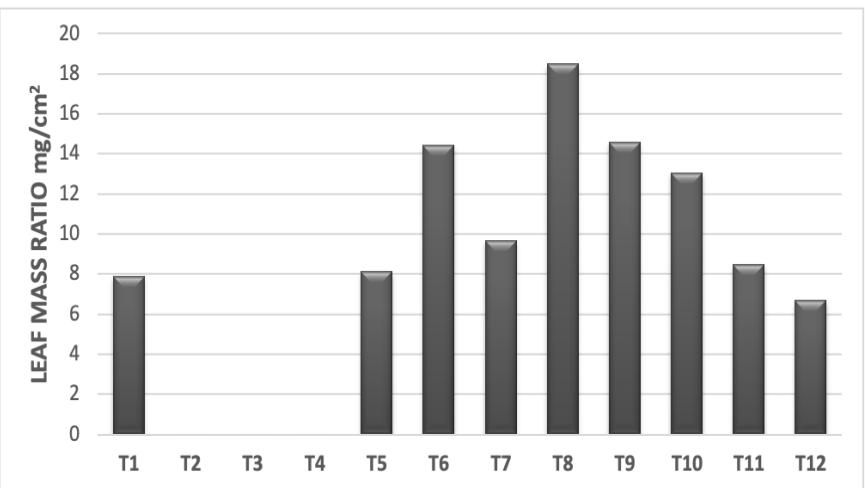

C

Figure 3: Effect IBA concentration and cutting types on (a) Leaf Area, (b) Specific Leaf Area, (c) Leaf Mass Ratio and (d) Dry Leave Weight in Berberis lycium.

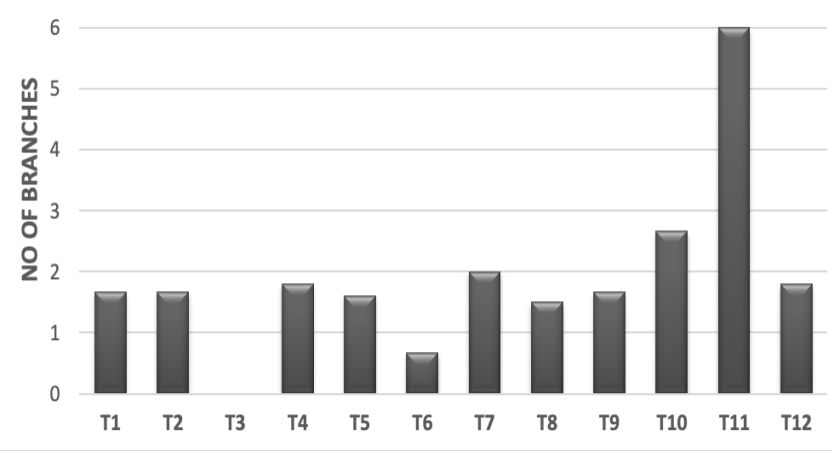

b

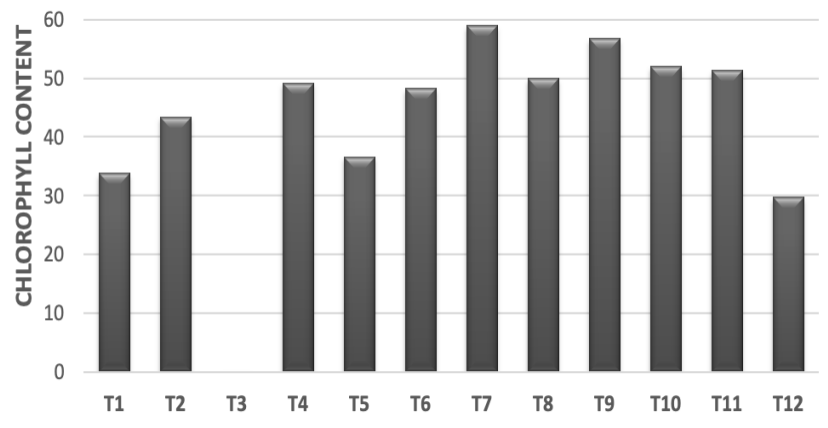

d

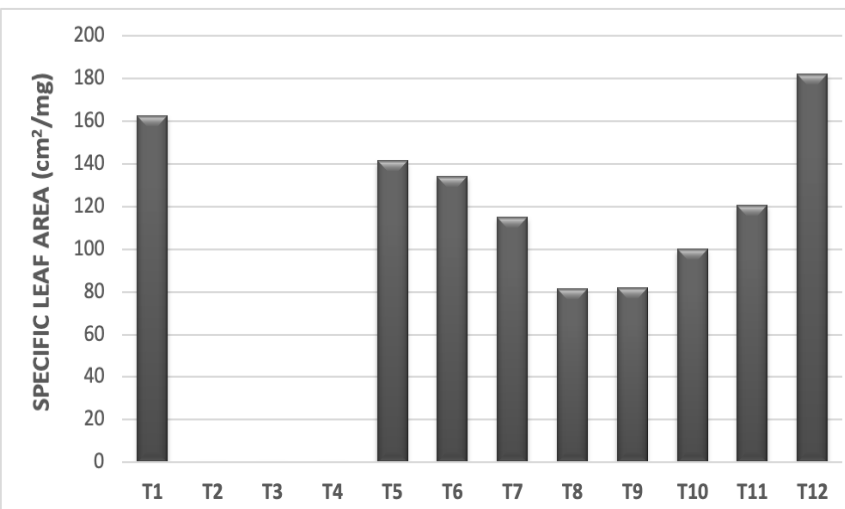

b

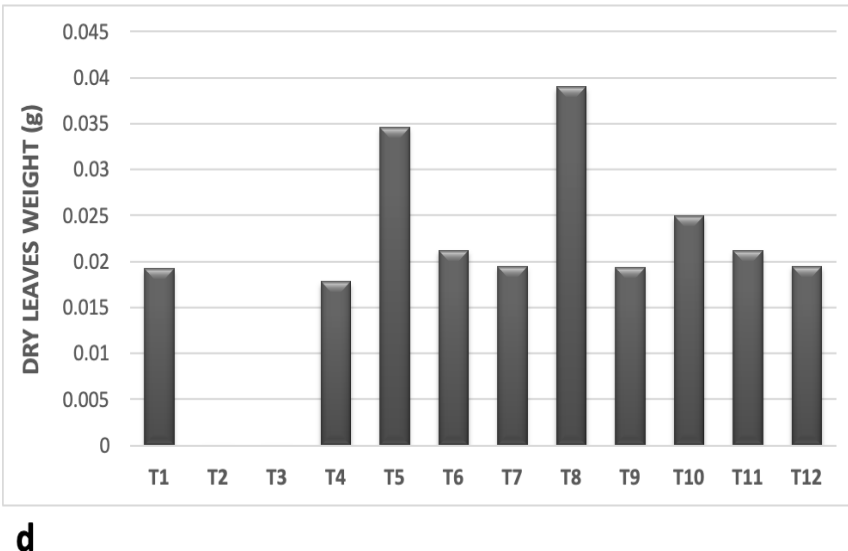

d 
Table 1: ANOVA mean square and P-value.

$\begin{array}{llllllllll}\text { SOV } & \text { D.F } & \text { D.B.S } & \text { SP } & \text { SL } & \text { SD } & \text { SW } & \text { NB } & \text { FLW } & \text { CC } \\ \text { Treatments } & 11 & 3.50045 & 1373.90 & 303.591 & 3.62 & 63.1683 & 6.234 & 0.03992 & 779.5555 \\ \text { Error } & 24 & 9.3418 & 3.78 & 89.95 & 0.11 & 0.7277 & 0.4730 & 0.02407 & 4.108 \\ \text { P-Value } & -- & 0.9219 & 0.0000 & 0.0000 & 0.0000 & 0.0000 & 0.0000 & 0.0987 & 0.0000 \\ \text { SOV } & \text { LA } & \text { SLA } & \text { LMR } & \text { DLW } & \text { NR } & \text { RL } & \text { FRW } & \text { RD } & \text { SV } \\ \text { Treatments } & 8.5525 & 16666.5 & 172.168 & 5.763 & 13.6826 & 240.088 & 4.20186 & 1.89751 & 2506.14 \\ \text { Error } & 1.2547 & 4615.6 & 42.648 & 7.244 & 8.6067 & 72.616 & 0.15411 & 0.20433 & 4.29 \\ \text { P-Value } & 0.0000 & 0.0006 & 0.002 & 0.0000 & 0.167 & 0.0075 & 0.0000 & 0.0000 & 0.0000\end{array}$

DBS: Days to Bud Sprouting; FLW: Fresh Leave Weight; NR: Number of Root; SP: Sprouting Percentage; CC: Chlorophyll Content; RL: Root Length; SL: Shoot Length; LA: Leaf Area; FRW: Fresh Root Weight; SD: Shoot Diameter; SLA: Specific Leaf Area; RD: Root Diameter; SW: Shoot Weight; LMR: Leaf Mass Ratio; SV: Survival Percentage; NB: Number of Branches; DLW: Dry Leaf Weight.

\section{Chlorophyll content}

Data regarding Chlorophyll content is represented in Figure 2 while its ANOVA is given in Table 1. Plant Chlorophyll content was significantly $(\mathrm{P} \leq 0.05)$ affected by IBA concentration and types of stem cutting. Maximum Chlorophyll content (58.967) was observed in semi hard wood cutting treated with IBA 6000 ppm. While minimum chlorophyll content (29.70) was recorded in hard wood cutting in control.

\section{Leaf area $\left(\mathrm{cm}^{2}\right)$}

Data regarding Leaf Area as affected by different concentration of IBA and cutting types are shown in Figure 3 while its ANOVA is presented in Table 1.

Plant leaf area was significantly $(\mathrm{P} \leq 0.05)$ affected by different IBA concentration and types of cutting. Maximum leaf area $\left(4.4857 \mathrm{~cm}^{2}\right)$ in semi hard cutting treated with IBA $2000 \mathrm{ppm}$ while minimum leaf area was recorded $\left(1.500 \mathrm{~cm}^{2}\right)$ hard wood cutting treated with 2000 ppm.

\section{Specific leaf area $\left(\mathrm{cm}^{2} / \mathrm{mg}\right)$}

Data regarding specific leaf area as affected by different concentration of IBA and cutting types are shown in Figure 3 while its ANOVA is presented in Table 1.

Specific leaf area was significantly $(\mathrm{P} \leq 0.05)$ affected by IBA concentration and types of stem cutting. Maximum specific leaf area $\left(182.31 \mathrm{~cm}^{2} / \mathrm{mg}\right)$ was observed in hard wood treated in control ppm while minimum specific leaf area $\left(0.00 \mathrm{~cm}^{2} / \mathrm{mg}\right)$ was notice in soft wood cutting treated with IBA $4000 \mathrm{ppm}$ and IBA 6000 ppm. Wright et al. (2004) studied the leaf traits and leaf areas correlation with plants photosynthesis capacity and nitrogen and phosphorus concentration and have found positive correlation with leaf areas. Which plants with high specific leaf area will have high photosynthesis activities and will accommodate more metabolites.

\section{Leaf mass ratio $\left(\mathrm{mg} \cdot \mathrm{cm}^{-2}\right)$}

Data regarding leaf mass ratio as affected by different concentration of IBA and cutting types are shown in Figure 3, while its ANOVA is shown in Table 1.

Leaf mass ratio was significantly $(\mathrm{P} \leq 0.05)$ affected by IBA concentration and types of stem cutting. Maximum leaf mass ratio $\left(18 \mathrm{mg} / \mathrm{cm}^{2}\right)$ was observed in Semi hard wood cutting in control while minimum leaf mass ratio $\left(0.00 \mathrm{mg} / \mathrm{cm}^{2}\right)$ was notice in soft wood cutting treated with IBA 4000 ppm and IBA 6000 ppm.

\section{Dry leaves weight $(g)$}

Data regarding dry leaves weight as affected by different concentration of IBA and cutting types are shown in Figure 3, while its ANOVA is presented in Table 1.

Plant dry leaves weight was significantly $(\mathrm{P} \leq 0.05)$ affected by different IBA concentration and types of cuttings. Maximum plant dry leaves weight (0.0390 g) was notice in semi hard wood cutting in control while minimum plant dry leaves weight $(0.0178$ g) soft wood cutting in control. The finding is also supported by Kumar (1994) who reported the rooting potential increase in Berberis lycium when cutting were treated with IBA. Similarly, Ali et al. (2008) also reported higher rooting percentage in $B$. aristata cutting treated with IBA. 


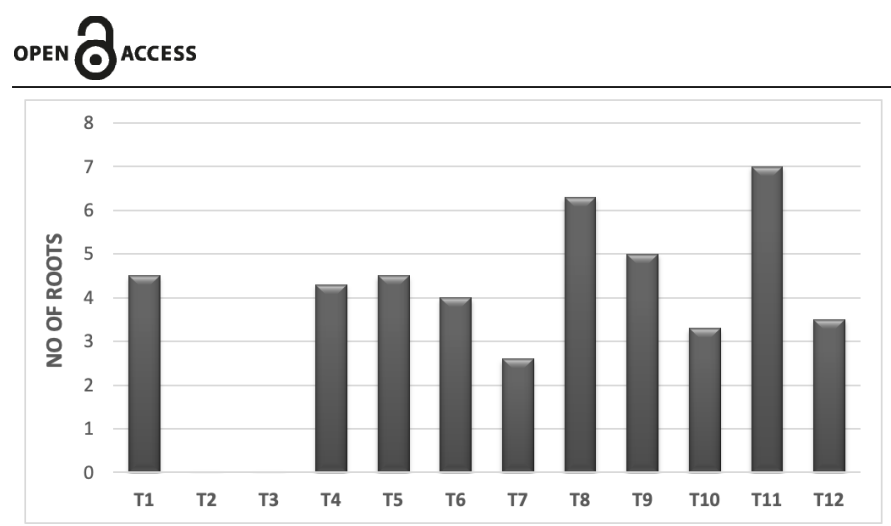

a

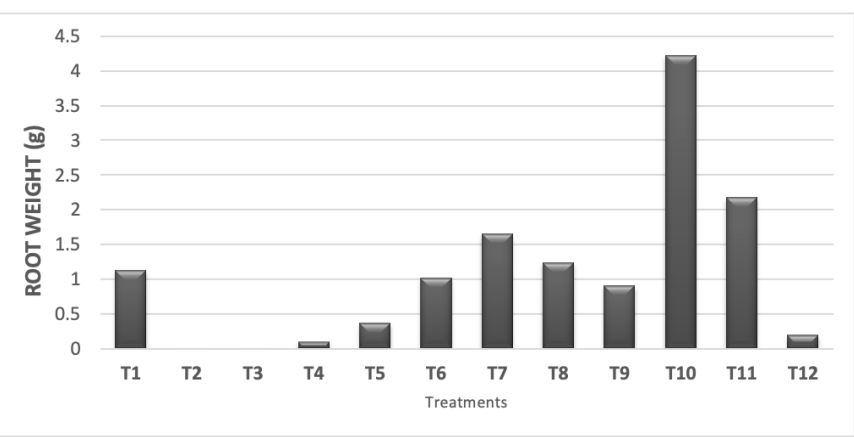

C

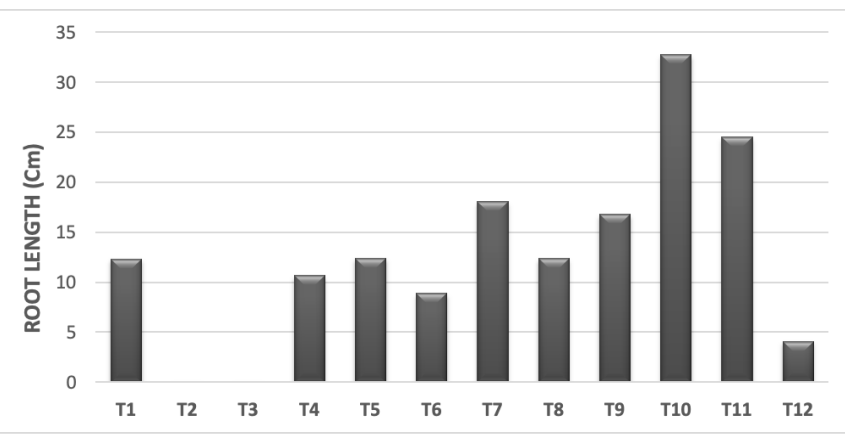

b

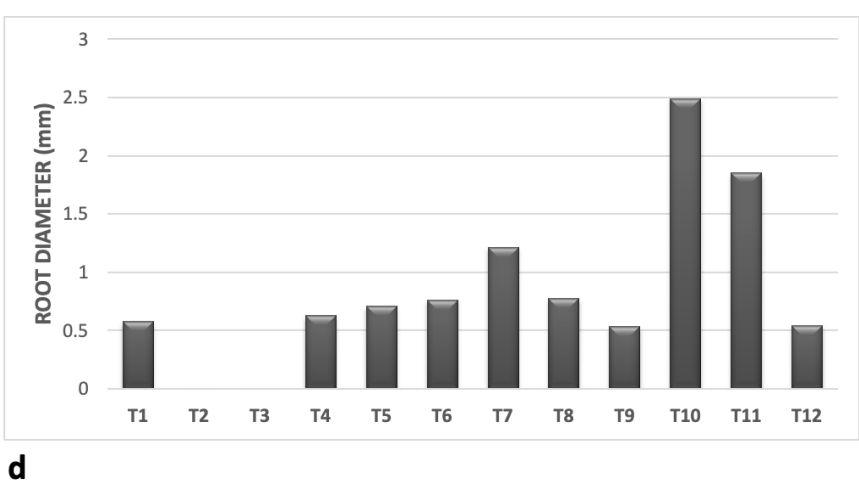

Figure 4: Effect of IBA concentration and cutting types on (a) Number of roots (b) Root length (cm), (c) Fresh root weight and (d) Root diameter in Berberis lycium.

\section{Number of roots plant ${ }^{-1}$}

Data regarding number of roots as affected by different concentration of IBA and cutting types are shown in Figure 4, while its ANOVA is presented in Table 1.

Types of cutting and IBA concentration had nonsignificantly $(P \leq 0.05)$ affected number of roots in plants. Maximum number of roots (7) was notice in hard wood cutting treated with IBA 6000 ppm while minimum number (2.6) of roots was recorded in semi hard wood cutting treated with IBA $6000 \mathrm{ppm}$. The roots are the primary interface between the plants and its external resources for the nutrient and water exchange. Generally, it is confirmed facts that mature wood has more accumulated store food which is the reason that more number of roots are recorded for hard wood cutting. Similarly, early sprouting in hard wood cutting may promoted the enhanced the root growth and development. The result is supported with finding of Ali et al., 2008 who reported that rooting potential increase with treating the cutting with IBA as compare to untreated cutting.

\section{Root length (cm)}

Data regarding root length as affected by different concentration of IBA and cutting types are shown in Figure 4, while its ANOVA is presented in Table 1.
Root length was significantly $(\mathrm{P} \leq 0.05)$ affected by IBA concentration and types of stem cutting. Maximum root length $(32.75 \mathrm{~cm})$ was observed in hard wood treated with IBA $4000 \mathrm{ppm}$ while minimum root length $(8.88 \mathrm{~cm})$ was notice in semi hard wood cutting treated with IBA 4000 ppm. Roots not only provide support to the plants but also provide nutrients and water uptakes. Generally, the root length per unit volume of soil is larger in surface area as compared to the subsoil. Therefore, dense root system of architect is commonly observed in top soil which support the plants in water and nutrient uptakes. The role of IBA in root promotion and callusing has been reported by Tanimoto (2005). The finding is also in agreement with the Ali et al. (2008) who reported higher rooting percentage in B. aristata cutting treated with IBA.

\section{Fresh root weight (g)}

Data regarding fresh root weight as affected by different concentration of IBA and cutting types are shown in Figure 4, while its ANOVA is presented in Table 1.

Fresh root weight was significantly $(\mathrm{P} \leq 0.05)$ affected by types of stem cutting and IBA concentration. Maximum root weight $(4.2267 \mathrm{~g})$ was observed in hard wood cutting treated with IBA 4000 ppm while minimum fresh root weight $(0.0950 \mathrm{~g})$ was recorded 
in soft wood cutting in control. Auxins promote and enhance callus and rooting in many woody forest and horticulture tree and shrubs. The role of IBA in rooting has been confirmed and validated by number of researchers. The results are in consistent with the finding (Ali et al., 2008) in which the Berberis aristata cutting showed increase no of rooting and root weight. Similarly, the role of IBA in root induction and promoting cell division and cell expansion was also confirmed by Frick and Strader (2017).

\section{Roots diameter $(\mathrm{mm})$}

Data regarding roots diameter as affected by different concentration of IBA and cutting types are shown Figure 4, while its ANOVA is presented in Table 1.

Plant roots diameter was significantly $(\mathrm{P} \leq 0.05)$ affected by types of cutting and IBA concentrations. Maximum roots diameter $(2.49 \mathrm{~mm})$ was recorded in hard wood cutting treated with IBA $4000 \mathrm{ppm}$. While minimum roots diameter $(0.5320 \mathrm{~mm})$ was notice in hard wood cutting treated with IBA 2000 ppm. Pacholczak et al. (2006) studied the effect of shading and IBA on rooting of berberis cutting. It was found that foliar application of IBA and shading of stock plant before cutting has significant effect on roots growth. The finding is also in agreement with the Ali et al. (2008) who reported higher rooting percentage, root length, fresh and dry root weight in $B$. aristata cutting treated with IBA.

\section{Survival percentage}

Data regarding plant survival percentage as affected by different concentration of IBA and cutting types are shown in Figure 5, its ANOVA is presented in Table 1.

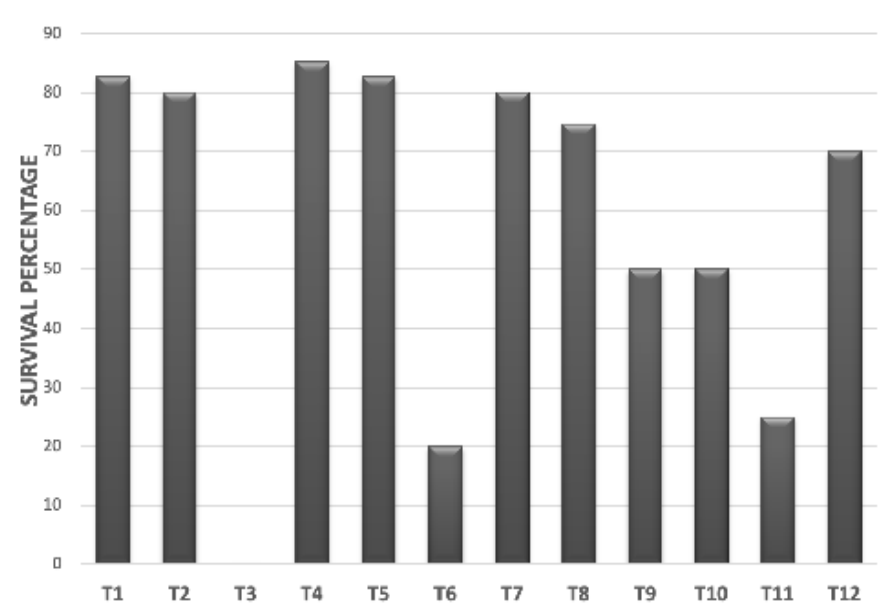

Figure 5: Effect IBA concentration and cutting types on survival percentage.
Plant survival percentage was significantly $(\mathrm{P} \leq 0.05)$ affected by types of cutting and different concentration of IBA. Maximum survival percentage (85.23\%) was observed in soft wood cutting in control while lowest survival percentage $(25 \%)$ was notice in hard wood cuttings treated with IBA 6000 ppm. Similarly, highest leaves area, dry leaves weight, leaf area, chlorophyll content was higher in semi hard and soft wood as compare to hard wood cutting which implies that although due to store food the hard wood cutting have sprouted early due to high store food content but fail to survive.

\section{Conclusions and Recommendations}

The results had shown that sprouting \% was highest (99.33) in hard wood cutting while minimum sprouting $(20 \%)$ soft wood cutting treated with IBA 6000 ppm while highest survival rate of 85.23 in soft wood cutting, highest sprout weight of 14.37 $\mathrm{g}$, highest shoot length (30.8) and maximum number of Branches (6) was found in hard wood cutting treated with IBA 6000 while maximum fresh root weight $(4.2267 \mathrm{~g})$, maximum root length (32.75 $\mathrm{cm})$ and highest root diameter $(2.49 \mathrm{~mm})$ in hard wood cutting treated with IBA $4000 \mathrm{ppm}$. As root length, and roots weight was recorded was recorded highest in hard wood cutting with IBA 4000 ppm is recommended for the production of Berberis lycium.

Based on the current experiment data analysis and synthesis the following conclusions may be drawn. The propagation of Berberis lycium is cost effective to propagate it through cutting as compare to tissue culture micro propagation. Hardwood cutting type perform better in most of the studied parameter i.e. root length, and roots weight was recorded was recorded highest in hard wood cutting with indole butyric acid $4000 \mathrm{mg} / \mathrm{L}$. Therefore, the propagation of Berberis lycium is recommended through hardwood cutting with indole butyric acid concentration of $4000 \mathrm{mg} / \mathrm{L}$.

\section{Novelty Statement}

The Berberis lycium is an important medicinal plant found in wild forest in Northern area of Pakistan. Due to its excessive use the wild plant endanger so in the current experiment its propagation and production protocol has been reported for cultivating it's commercially for herbal industry. 


\section{Author's Contribution}

Tahseen Ullah: Conceived idea and wrote abstracts, results and discussion.

Noor U1 Amin: Overall management of the article.

\section{Conflict of interest}

The authors have declared no conflict of interest.

\section{References}

Ali, M., A.R. Malik and K.R. Sharma. 2008. Vegetative propagation of berberis aristata dc. An endangered himalayan shrub. J. Med. Plants Res., 2(12): 374-377.

Atwell, B.J., C.G.N. Turnbull and P.E. Kriedemann.1999. Plants in action: Adaptation in nature, performance in cultivation 664 Melbourne Macmillan education Australia.

Bhardwaj, D. and N. Kaushik. 2012. Phytochemical and pharmacological studies in genus Berberis. Phytochem. Rev., 11(4): 523-542. https://doi. org/10.1007/s11101-013-9272-x

Frick, E.M. and L.C. Strader. 2001. Roles for IBAderived auxin in plant development. J. Exp. Bot., 69(2): 169-177. https://doi.org/10.1093/ jxb/erx298

Frick, E.M. and L.C. Strader. 2017. Roles for IBAderived auxin in plant development. J. Exp. Bot., 69(2):169-177. https://doi.org/10.1093/ jxb/erx298

Ikram, M., 1975. A review on the chemical and pharmacological aspects of genus Berberis. Plant. Med., 28(8): 353-358. https:// doi.org/10.1055/s-0028-1097869

Jan, M.T., P. Shah, P.A. Hollington, M.J. Khan and Q. Sohail. 2009. Agriculture research: Design and analysis. $1^{\text {st }}$ Ed. Deptt. Agron. Univ. Agric. Peshawar, Pakistan

Karimov, A., 1993. Berberis alkaloids. Chem. Nat. Compd., 29(4): 415-438. https://doi. org/10.1007/BF00630564

Kumar, V., 1994. Propagation of some important shrubs of mid Himalayas through seed and stem cuttings (Doctoral dissertation, DYSP UHF Solan).

Pacholczak, A., W. Szydło and A. Łukaszewska. 2006. The effect of shading of stock plants on rhizogenesis in stem cuttings of Berberis thunbergii Red Rocket. Acta Physiol. Plant, 28(6): 567-575. https://doi.org/10.1007/ s11738-006-0052-8

Polunina, O.V., V.P. Maiboroda and A.Y. Seleznov. 2018. Evaluation methods of estimation of young apple trees leaf area. Вісник Уманського національного університету садівництва, 2: 80-82. https://doi.org/10.31395/2310-04782018-21-80-82

Rao, R.R., T.Husain, B.Dutt and A. Garg. 1998. Revision of the family berberidaceae of India-I. Rheedea-Kerala 8(1): 1-66.

Rao. R.R. and P.K. Hajra. 1993. Berberis In: Sharma, B.D., N.P. Balakrishnan, R.R. Rao and Hajra, P.K. (ed.). Flora of India. Calcutta, India. pp. 415-438.

Shabbir, A., M.Shahzad, Y. Arfat, L. Ali, R.S. Aziz, G. Murtaza and S.A. Waqar. 2012. Berberis lycium Royle: A review of its traditional uses, phytochemistry and pharmacology. Afr. J. Pharm. Pharmacol., 6(31): 2346-2353. https:// doi.org/10.5897/AJPP12.927

Tanimoto, E., 2005. Regulation of root growth by plant hormones roles for auxin and gibberellin. Crit. Rev.Plant Sci., 24(4): 249-265. https://doi.org/10.1080/07352680500196108

Ullah, T., F.U. Wazir, M. Ahmad, F. Analoui and M.U. Khan. 2005. A break through in guava (Psidium guajava L.) propagation from cutting. Asian J. Plant Sci., 4(3): 238-243. https://doi. org/10.3923/ajps.2005.238.243

Wright, I.J., P.K. Groom, B.B. Lamont, P. Poot, L.D. Prior, P.B. Reich and M. Westoby. 2004. Leaf trait relationships in Australian plant species. Funct. Plant Biol., 31(5): 551-558. https://doi.org/10.1071/FP03212 